\title{
Determination of Mechanical Properties of Aged Wood Material Using Vickers Microhardness Test
}

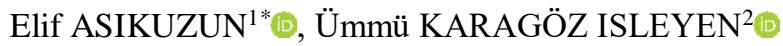 \\ ${ }^{1}$ Kastamonu University, Department of Metallurgy and Material Engineering, Kastamonu, TURKEY \\ ${ }^{2}$ Kastamonu University, Department of Forest Industry Engineering, Kastamonu, TURKEY \\ *Corresponding author: easikuzun@kastamonu.edu.tr
}

Received Date: 20.12.2018

Accepted Date: 12.02 .2019

\section{Abstract}

Aim of study: In this study, it was aimed to determine the changes under the influence of time of the age wood obtained from the historical wooden buildings.

Area of study: The aged wood (AW) and new wood (NW) were used in experimental analysis. Wood samples were Pinus sylvestris L. The aged wood was over 50 years old and is derived from the historical wooden buildings in Kastamonu, Turkey.

Material and Methods: The aged and new wood samples were prepared to compare the effect of time. The mechanical properties, crystallinity and microstructure of new and aged wood were investigated by using Vickers microhardness tester, XRD and SEM, respectively. The change in the mechanical and structural properties of the aged and new wood material was determined.

Main results: The microhardness values depended on the applied load and increased with increasing the applied load. Meyer's law, Proportional Sample Resistance, Elastic/Plastic Deformation, Hays-Kendall Approach and Indentation-Induced Cracking models were analyzed for investigation of load independent microhardness values. As a result, IIC model was the most successful model.

Research highlights: It is very important to know the changes that wood has suffered in time in order to conservation of wooden cultural heritage objects and reuse of aged wood.

Keywords: Aged wood, new wood, historical construction, cultural heritage, vickers microhardness

\section{Vickers Mikro Sertlik Testi Kullanılarak Yaşlı Ahşap Malzemelerin}

\section{Mekanik Özelliklerinin Belirlenmesi}

$\ddot{O} \mathbf{z}$

Çalışmanın amacı: Bu çalışmada, tarihi ahşap binalardan elde edilen yaşlı ahşabın zaman etkisi altındaki değişimlerinin belirlenmesi amaçlanmıştır.

Çalışma alant: Deneysel analizde yaşlı ahşap (AW) ve yeni ahşap (NW) kullanılmıştır. Ahşap örneklerinin türü Pinus sylvestris L.' tir. Yaşlı ahşap 50 yaşın üzerinde olup, Kastamonu'daki tarihi ahşap binalardan elde edilmiştir.

Materyal ve Yöntem: Yaşlı ve yeni ahşap örnekleri zamanın etkisini karşılaştırmak için hazırlanmıştır. Yeni ve yaşlı ahşapların mekanik özellikleri, kristalliği ve mikro yapısı sırasıyla Vickers mikrosertlik, XRD ve SEM cihazları kullanılarak incelenmiştir. Yaşlı ve yeni ahşap malzemenin mekanik ve yapısal özelliklerinde meydana gelen değişimler tespit edilmiştir.

Temel Sonuçlar: Numunelerin mikrosertlik değerleri uygulanan yüke bağlıdır ve yük arttıkça mikrosertlik değeri artmışırı. Meyer kanunu, orantılı numune direnci (PSR), elastik/plastik deformasyon (EPD), Hays-Kendall (HK) yaklaşımı ve çentici kaynaklı yarılma (IIC) modelleri yükten bağımsız mikrosertlik değerlerinin araştırılması için analiz edilmiştir. Sonuç olarak IIC modeli en başarılı model olarak belirlenmiştir.

Anahtar Kelimeler: Yaşlı ahşap, yeni ahşap, tarihi yapı, kültürel miras, vickers mikrosertlik

\section{Introduction}

The use of wood as a building material has a long history in architecture. Wood has an important place in the construction industry because of its usability in different architectural designs, ease of working, aesthetic beauty and high strength-density ratio. Our cultural heritage has many hundreds of years of wood objects and constructions. Wooden constructions, a part 
of the cultural heritage, reflect the social, cultural and economic life of past centuries and directly convey information to the future. So, the conservation of the wood cultural heritage is quite important from a cultural point of view.

The physical, mechanical and chemical degradation in the wood material exposed to various environmental effects for long term years begins to occur. Factors leading to degradation in historical wooden structures of cultural heritage are as follows; ambient air effect (temperature, UV, climate change, precipitation, snow, frozen, moisture content), biological attacks (fungi, insect), time, natural disaster (earthquake, flood), metal-to-wood interaction, the history and period of load acting on the structure (Unger, Schniewind \& Unger, 2001). Knowing the structural changes occurring in the wood during the time is very important in terms of the conservation of historic wooden structures and the reuse of aged wood in recycling (Kranitz, 2014). In the literature, the effects of aging on the physical, chemical and mechanical changes in the historical aged wood material are widely discussed (Kranitz, 2014; Kranitz, Sonderegger, Bues \& Peter, 2016; Sonderegger, Kránitz, Bues \& Niemz, 2015).

The chemical degradation in the wood material exposed to direct sunlight and outdoor condition occurred due to aging. A decrease in the amount of lignin which is sensitive to UV-light was determined. At the same time, it is stated that degradation of wood material components due to aging mostly affects hemicelluloses and occur decrease in amount of hemicelluloses. Also, the chemical changes of wood were generally obtained at the age of 120 years and over, depending on the ambient conditions. (Matsuo, Yokoyama \& Umemura, 2011; Inagaki, Yonenobu \& Tsuchikawa, 2008; Kuo and $\mathrm{Hu}, 1991$ ).

The mechanical properties of the timber material which has the load bearing behavior in the historical wooden structures are affected by insect degradation or decay, long term load, material qualities, earthquake in over time. Mechanical properties are decreased due to biological attacks. The many researches were published related to the effect of the aging and load history and duration on the mechanical properties of wood (Fridley, Mitchell, Hunt, \& Senft, 1996; Ooka, Tanahashi, Izuno, Suzuki \& Toki, 2012; Ando, Hirashima, Sugihara, Hirao, \& Sasaki, 2006; Feio \& Machado, 2015). In literature, the effects of age on chemical, physical and mechanical properties of wood material were obtained differently (Popescu et al., 2007). The results are not always in agreement and the influence of aging on changes in physical and mechanical properties is generally unclear. The reasons for this disagreement are as follows: lack of information about the duration and history of load and the state of conservation of aged wood, to check the mechanical properties of age and new wood (Alberto et al.,2016), mechanical properties variability, unclear associated with the actual mechanical properties of aged wood, different research approaches:

In this study, the effect of age on the mechanical properties of aged wood materials obtained from historical structures was investigated. The new wood samples were used to compare the structural and mechanical changes of aged wood samples. Also, Micro hardness properties were used to determine the mechanical properties of aged and new wood materials. The surface characteristics of aged and new wood samples were determined by SEM and the crystallinity of the samples was evaluated with XRD.

\section{Material and Method}

The aged wood materials were collected from historic wooden buildings over the age of 50 years. Wood species are Pinus sylvestris. There was no information about the status of aged wood in the structure and the load carrying time. Also new wood samples were prepared for understanding aged effect. The aged wood was compared with new wood samples in terms of structural and mechanical properties. Especially, mechanical properties were investigated in details. The aged and new wood samples with dimensions of 20x20x30 mm were produced and were conditioned at $65 \%$ relative humidity and $20^{\circ} \mathrm{C}$ temperature. The density value $\left(0.458 \mathrm{~g} / \mathrm{m}^{3}\right)$ of aged wood and density value $\left(0.460 \mathrm{~g} / \mathrm{cm}^{3}\right)$ of new wood was determined according to EN 384 . 
Microhardness properties were used to determine the mechanical properties of aged and new wood materials (Fig.1). The cellulose crystallinity and micro structure of new and aged wood were obtained by using XRD (Fig.2) and SEM (Fig.3) devices, respectively.

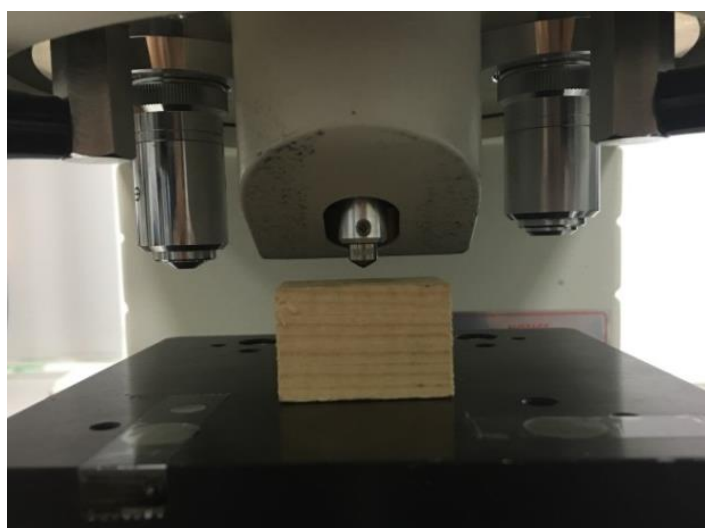

Figure 1. HMV Microhardness Device (SHIMADZU)

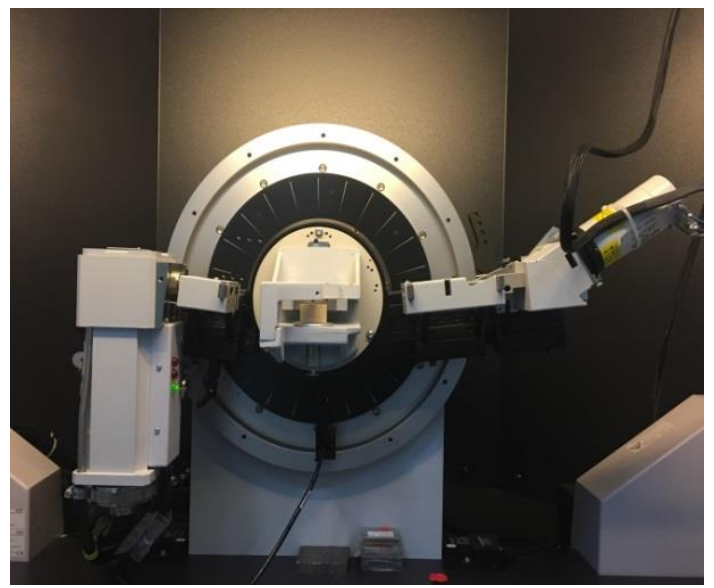

Figure 2. X-Ray Diffractometer

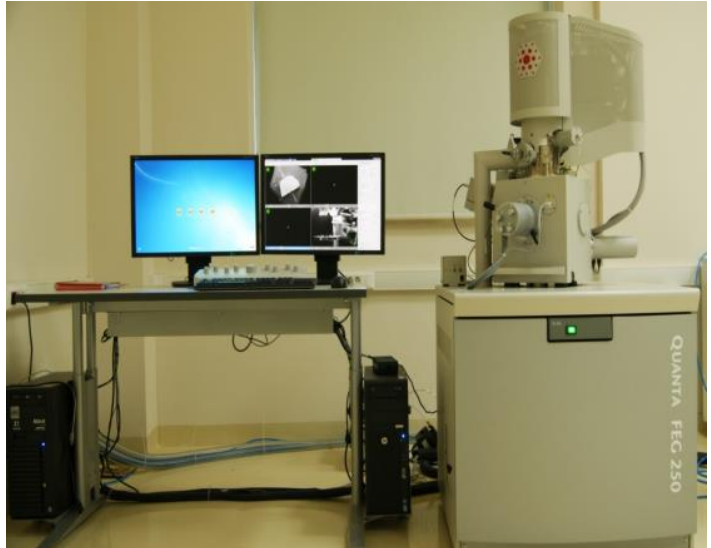

Figure 3. Scanning Electron Microscopy (Quanta FEG 250)

\section{Result and Discussion}

\section{Analyses of Structural Properties Using The XRD and SEM measurements}

XRD measurement was performed by a Bruker D8 Advance model diffractometer with $\mathrm{CuK}_{\alpha}$ radiation $(\lambda=1.541 \AA)$ in the range $2 \theta=5-60^{\circ}$ at a scan speed of $4 \mathrm{deg} / \mathrm{min}$ at room temperature. X-Ray patterns of samples were given in Fig. 1. It is clearly seen that NW and AW have one characteristic crystalline peaks at $2 \Theta=22.7^{\circ}$ approximately (Fig. 4). This dominant peak was along the (002) plane and used for the crystallinity index calculation (Eqn.1). Crystalline index (\%) of NW and AW were found 70.84 and 57.81, respectively in which calculated from $\mathrm{I}_{002}$ crystalline intensity and $\mathrm{I}_{\mathrm{am}}$ intensity at $2 \Theta=19.7$. Crystalline index decreased with increasing the years. The main reason of decreasing crystalline index of samples can be thought as decreasing of the cellulose amount over the years. Moreover, the amorphous property increased of AW sample.

$$
C R I_{W}=\left[\left(I_{002}-I_{a m}\right) /\left(I_{002}\right)\right] * 100
$$

Surface morphology of the samples was performed by JEOL JSM-7000F SEM. 500 and 1000 magnifications of SEM images were given Fig.5. As can be seen from the images, it was observed that porosity increased with years. 


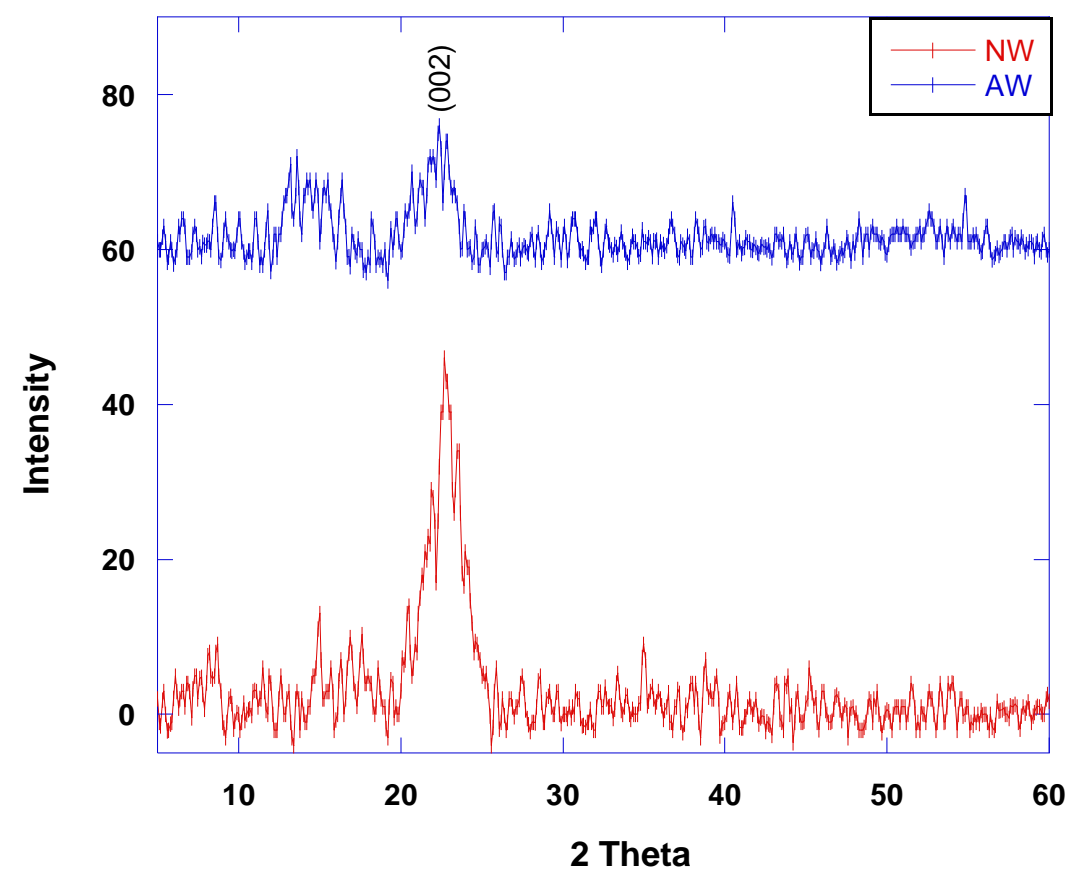

Figure 4. XRD patterns of wood samples
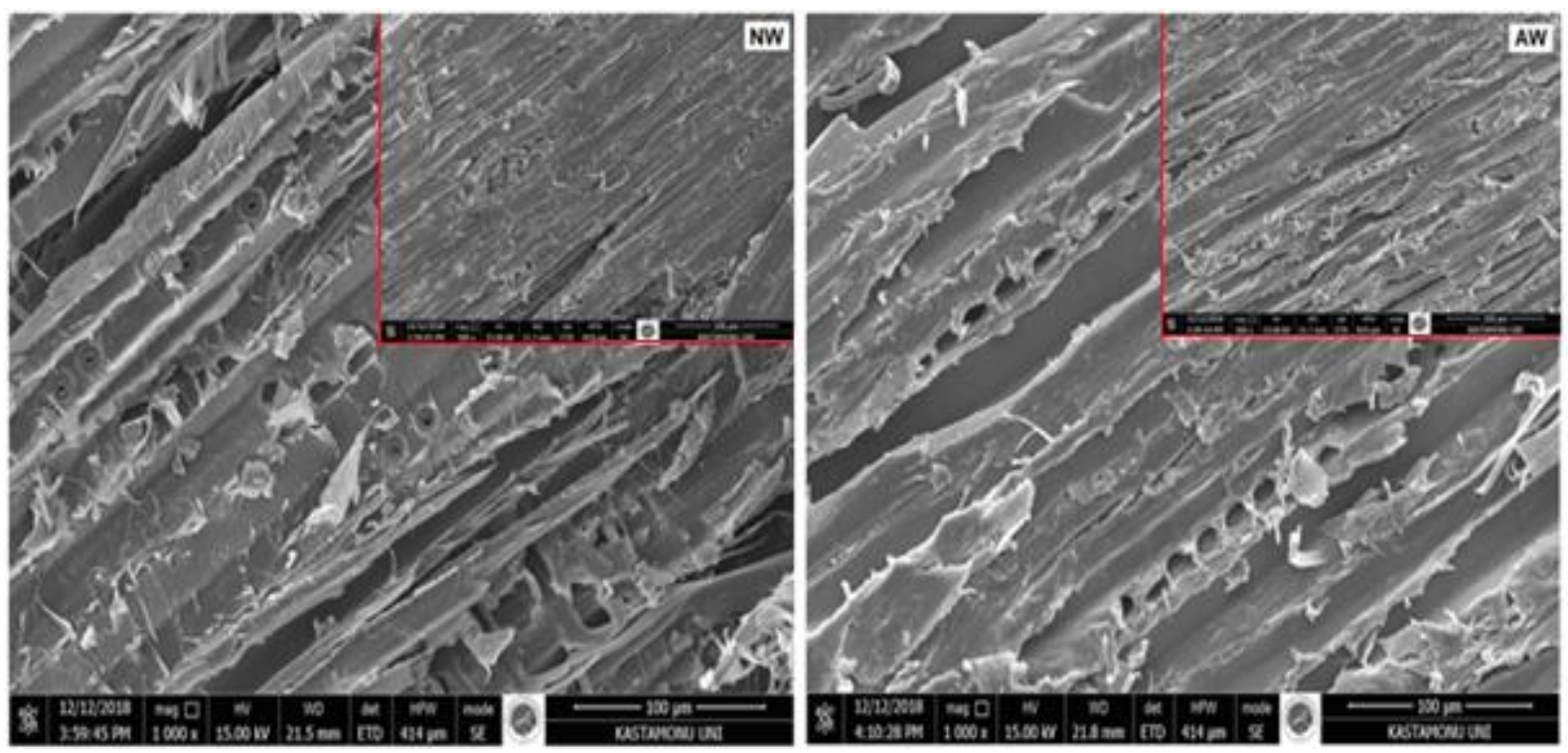

Figure 5. SEM images of wood samples 


\section{Analyses of Mechanical Properties Using The Vickers Microhardness Measurements}

The mechanical behavior is the reaction of a material against applied force. This behavior is determined by measuring the strain and deformations that occur under different stresses. Materials lose their strength and are broken since materials change shape under external stresses. The deformations under low stresses are elastic and reversible. When the strain exceeds the elastic limit, a permanent plastic deformation occurs. The bonding forces between atoms occur the basis of elastic and plastic deformation. It is very important to know the behavior and the exchange of bonding structures of atoms in the process of deformation. When determining the mechanical properties, the reaction of the material against the applied load is taken into consideration and this is called as hardness. This reaction depends on the type of material, the arrangement of atoms and bonding forces.

Hardness is described as measuring the response of the material against the applied load using a conical or spherical standard indenter. When the selected indenter is pressed on the surface of sample under an applied load, trace is formed on the surface of sample. The microhardness of the sample is inversely proportional with indentation size.

Vickers microhardness test was used in this study. In this test, indenter is immersed on the surface of the material under a load selected according to the material (such as 10 ,
$25,50,100,200,300,400,500 \mathrm{~g}$ and $1 \mathrm{~kg}$ ) with a certain period (such as 10,15 s) and diagonal length of indentation is measured. Vickers microhardness value;

$$
H_{v}=1854.4\left(F / d^{2}\right)
$$

was calculated using Eqn 2. Here $F$ is calculated as $\left(\mathrm{d}_{1}+\mathrm{d}_{2}\right) / 2$ and $d$ are applied load and diagonal length, respectively.

In this study, in order to investigate the aging on the mechanical properties, Vickers microhardness measurements were carried out. Measurements were taken from sample surfaces. $F$ was changed between $0.245-2.940$ $\mathrm{N}$ for $10 \mathrm{~s}$. Obtained values were designated with an average of 7 readings at different region of the sample surfaces.

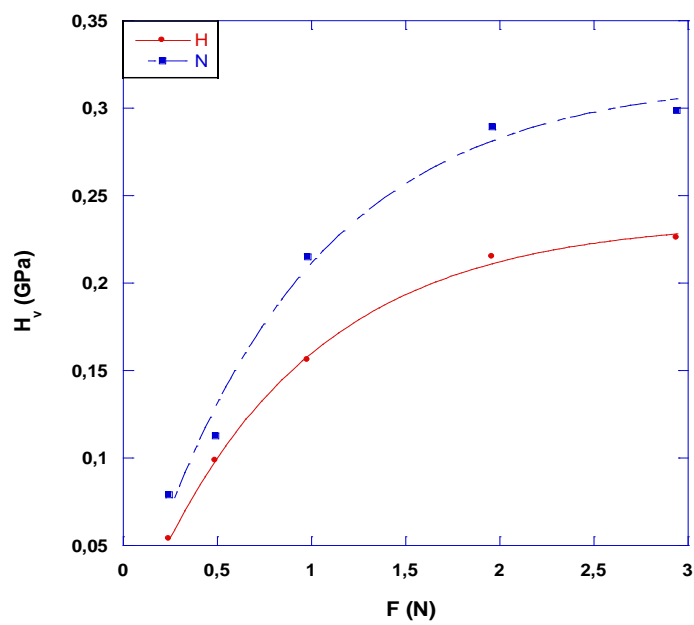

Figure 6.Change of $\mathrm{H}_{\mathrm{v}}$ versus applied load $\mathrm{F}$

Table 1. $\mathrm{H}_{\mathrm{v}}, \mathrm{E}$ and $\mathrm{Y}$ for the samples

\begin{tabular}{lccccc}
\hline Samples & $\mathrm{F}$ & $\mathrm{H}_{\mathrm{V}}$ & $\mathrm{E}$ & $\mathrm{Y}$ & $\mathrm{H}_{\mathrm{v}}(\mathrm{GPa})$ \\
& $(\mathrm{N})$ & $(\mathrm{GPa})$ & $(\mathrm{GPa})$ & $(\mathrm{GPa})$ & $($ in saturationregion) \\
\hline \multirow{4}{*}{$\mathbf{N W}$} & 0.245 & 0.079 & 6.475 & 0.026 & \\
& 0.490 & 0.112 & 9.179 & 0.037 & \\
& 0.980 & 0.215 & 17.62 & 0.071 & $0.289-0.298$ \\
& 1.960 & 0.289 & 23.68 & 0.096 & \\
& 2.940 & 0.298 & 24.42 & 0.099 & \\
$\mathbf{4} \mathbf{A W}$ & 0.245 & 0.053 & 4.344 & 0.017 & \\
& 0.490 & 0.098 & 8.032 & 0.032 & $0.214-0.225$ \\
& 0.980 & 0.155 & 12.700 & 0.051 & \\
& 1.960 & 0.214 & 17.540 & 0.071 & \\
\hline
\end{tabular}

It was clear seen from the Figure 6, all parameters depended on the applied load. In the literature, while interpreting the microhardness values of materials, two 
different types of material behavior are mentioned. The first one is ISE behavior (Indentation Size Effect) which is expressed as a decrease in the microhardness by the load applied on the surface of the material. These materials show both elastic deformation and plastic deformation. The second behavior is the RISE behavior (Reverse Indentation Size Effect). In this case, the material shows an increased microhardness value against the applied load. Furthermore, these materials show only plastic deformation.

In this study, as seen from Figure 6, the microhardness values increased with increasing the applied load. That is, the material exhibited the RISE behavior. In addition, the microhardness values of all samples reached a saturation (saturation region) at around $2 \mathrm{~N}$. This means that there was no significant change in the microhardness of the material at loads greater than $2 \mathrm{~N}$. When the AW and NW samples were compared, the microhardness of the AW sample was slightly reduced. This was an expected result. Decreasing cellulose content and increasing porosity may lead to a decrease in microhardness of AW sample depending on years.

When examining the mechanical properties of the materials, it is very important to know the parameters such as elastic modulus (E) and yield strength (Y) depending on the microhardness values of the samples. The obtained values were summarized in Table 1. According to the table, all of values were in the same tendency with microhardness behavior. $\mathrm{H}_{\mathrm{v}}, \mathrm{E}$ and $\mathrm{Y}$ values were significantly dependent on the applied load. This result was compatible with the literature (Tosun et al., 2014; Asikuzun et al., 2012; Safran et al., 2014).

$E=81.9635 H_{V}$

$Y \approx H_{V} / 3$

In the literature, there are many models developed for microhardness analysis of materials. These models are used to determine the behavior of the materials against the applied load (ISE or RISE). These are Meyer's Law, Proportional Sample Resistance Model (PSR), Elastic/ Plastic Deformation Model (EPD), Hays Kendall (HK) Approach and
Indentation Induced Cracking Model (IIC). The explanations and results of these models were given below.

\section{Analysis According to Meyer's Law}

Meyer's law is an empirical relation between the size of a hardness test indentation and the load required to leave the indentation (Li and Bradt, 1993; Gong, Wu \& Guan, 1999). The formula was given below.

$F=A d^{n}$

Here, $n$ is the Meyer index and is obtained from the slope of InF-Ind graph. Generally, while if the $n$ is smaller than 2, materials exhibit indentation size effect, if the $n$ is more than 2, materials exhibit reverse indentation size effect behavior (Quinn and Quinn, 1997; Ozturk et al., 2012). The $\ln d-\ln F$ graph of the samples was given in Figure 7. The Meyer index was greater than 2 for the examined samples. It confirmed that the load-dependent displacement character was RISE. These data were summarized in Table 2 .

Table 2. Values of $m$ and InK

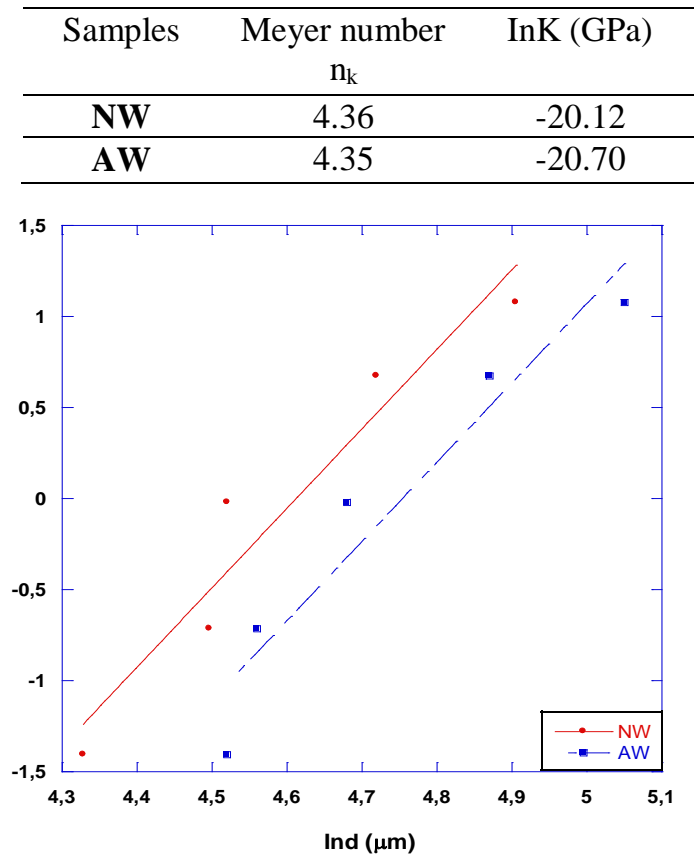

Figure 7. Change of InF against Ind for the wood samples

\section{Analysis According to PSR Model}

In the PSR model, it is stated that limit value of the sample resistance is not absent 
and goes up with indentation depth.The equation of this model was given below.

$F / d=\alpha+\beta d$

$\alpha$ and $\beta$ are related to an elastic deformation and plastic deformation, respectively. $\alpha$ is the value where $(F / d)-d$ axis intersected and $\beta$ is the slope of the line (Fig 8). According to the PSR model, microhardness values were calculated using the equation (7).

$$
H_{P S R}=1854.4 \beta
$$

The data obtained were summarized in Table 3 . As can be seen from the table, the $\alpha$ values of the samples showing RISE behavior were negative. It shown that there was no elastic deformation in all samples and only plastic deformation. If $H_{P S R}$ values were compared with value that corresponds to the saturation region, it can be seen clearly that these microhardness values were quite far from the saturation region. For this reason, it is apparent that the PSR model was inadequate to determine the true microhardness values of the samples.

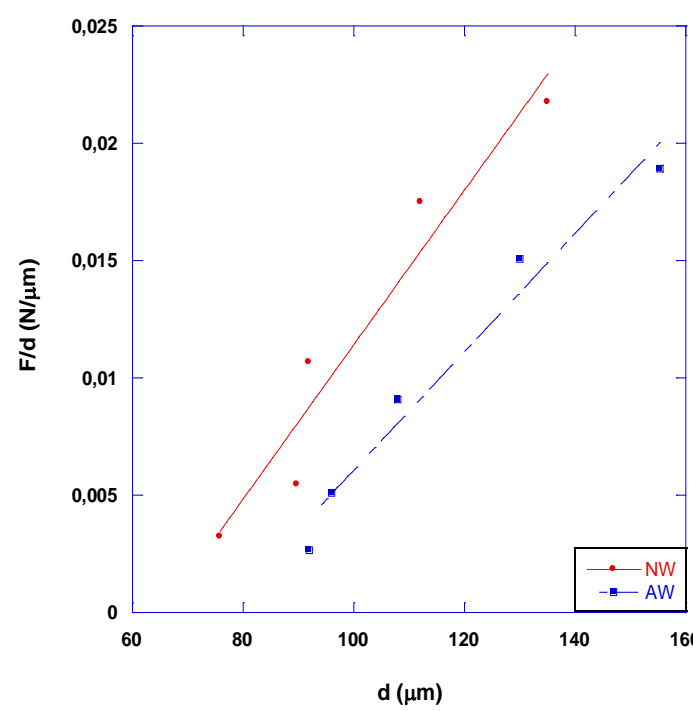

Figure 8. Change of F/d against $d$ for the wood samples
Table 3. Optimal results of experimental data according to PSR model

\begin{tabular}{ccccc}
\hline Samples & $\begin{array}{c}\alpha \times 10^{-2} \\
(\mathrm{~N})\end{array}$ & $\begin{array}{c}\beta \times 10^{-4} \\
(\mathrm{~N} / \mu \mathrm{m})\end{array}$ & $\begin{array}{c}\mathrm{H}_{\mathrm{PSR}} \\
(\mathrm{GPa})\end{array}$ & $\begin{array}{c}\mathrm{H}_{\mathrm{V}}(\mathrm{GPa}) \\
\text { (in } \\
\text { saturation } \\
\text { region) }\end{array}$ \\
\hline NW & -2.14 & 3.29 & 0.610 & $\begin{array}{c}0.289- \\
0.298\end{array}$ \\
\hline AW & -1.91 & 2.52 & 0.467 & $\begin{array}{c}0.214- \\
0.225\end{array}$ \\
\hline
\end{tabular}

\section{Analysis According to EPD Model}

Elastic recovery occurs around the indentation size formed after the indenter is removed from the sample surface. Thus, the indentation size is reduced a small amount. In this model, it is stated that a new term is added to the measured indentation size for calculate the load independent microhardness. The equation of EPD model is given below.

$F=A\left(d_{e}+d_{p}\right)^{2}$

$d_{e}$ and $d_{p}$ are associated with elastic and plastic deformation, respectively. $A$ and $d_{e}$ values were calculated from $F^{1 / 2}-d_{p}$ graph (Fig 9). In addition, microhardness value was defined by the following equation.

$H_{E P D}=1854.4 \mathrm{~A}$

These values were summarized in Table 4 . $d_{e}$ value found from the point where the graph intersects the $\mathrm{y}$ axis was negative for all samples. In another saying, no elastic deformation was observed for $F$. The microhardness values were so far from the saturation region. Consequently, EPD model was not sufficient. 


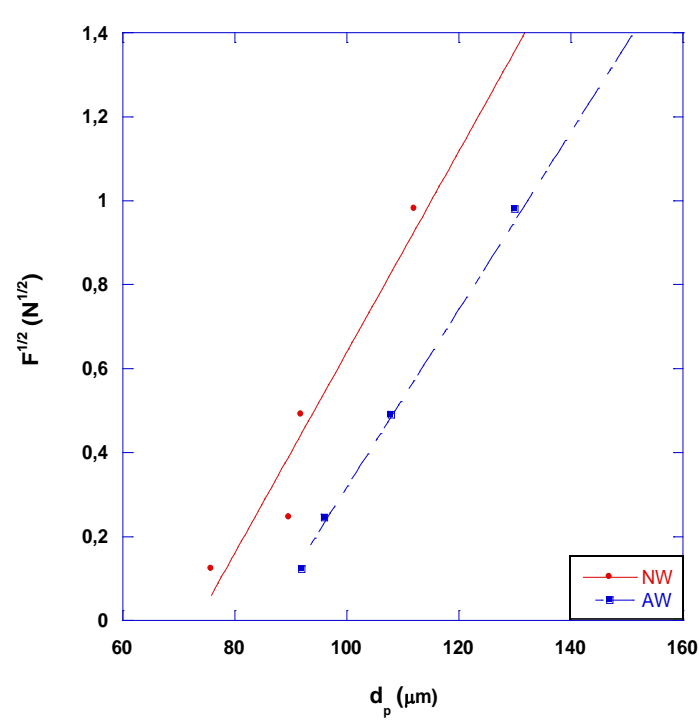

Figure 9. Change of $F^{1 / 2}$ against $d_{p}$ for the wood samples

Table 4. Optimal of experimental data according to EPD model

\begin{tabular}{ccccc}
\hline Samples & $\begin{array}{c}\mathrm{K}^{1 / 2} \\
(\mathrm{GPa})\end{array}$ & $\begin{array}{c}\mathrm{d}_{\mathrm{e}} \\
(\mu \mathrm{m})\end{array}$ & $\begin{array}{c}\mathrm{H}_{\mathrm{EPD}} \\
(\mathrm{GPa})\end{array}$ & $\begin{array}{c}\mathrm{H}_{\mathrm{V}} \\
(\mathrm{GPa})\end{array}$ \\
\hline \multirow{2}{*}{ NW } & 0.023 & -1.75 & 0.980 & $\begin{array}{c}0.289- \\
0.298\end{array}$ \\
\hline \multirow{2}{*}{ AW } & 0.021 & -1.79 & 0.817 & $\begin{array}{c}0.214- \\
0.225\end{array}$ \\
\hline
\end{tabular}

\section{Analysis According to HK Approach}

In this model, it is stated that only elastic deformation is observed when the applied test load is below a specific limit value. However, plastic deformation occurs above this limit value (Hays and Kendall, 1973). The equation of the model was given below.

$$
F-W_{H K}=A_{H K} d^{2}
$$

$\mathrm{W}$ is the load required to create the initial deformation. $W$ was the value where $F-d^{2}$ axis intersected and $\mathrm{A}_{\mathrm{HK}}$ was the slope of the line (Fig 10). Microhardness value was calculated using Eqn. (11).

$H_{H K}=1854.4 A_{H K}$

According to the $\mathrm{HK}$ approach, $\mathrm{W}_{\mathrm{HK}}$ values were negative. This result can be interpreted that the applied load was sufficient to form plastic deformation but insufficient for elastic deformation. In addition, the calculated microhardness values were quite different from the values of saturation region. It was clear that the HK model was not the appropriate model.

Table 5. Optimal results of experimental data according to EPD model

\begin{tabular}{ccccc}
\hline Samples & $\begin{array}{c}\mathrm{A}_{\mathrm{HK}} \times 10^{-} \\
(\mathrm{GPa})\end{array}$ & $\begin{array}{c}\mathrm{W}_{\mathrm{HK}} \\
(\mathrm{N})\end{array}$ & $\begin{array}{c}\mathrm{H}_{\mathrm{HK}} \\
(\mathrm{GPa})\end{array}$ & $\begin{array}{c}\mathrm{H}_{\mathrm{V}} \\
(\mathrm{GPa})\end{array}$ \\
\hline $\mathbf{N W}$ & 22.38 & -1.05 & 0.415 & $0.289-0.298$ \\
\hline AW & 17.03 & -1.07 & 0.315 & $0.214-0.225$ \\
\hline
\end{tabular}

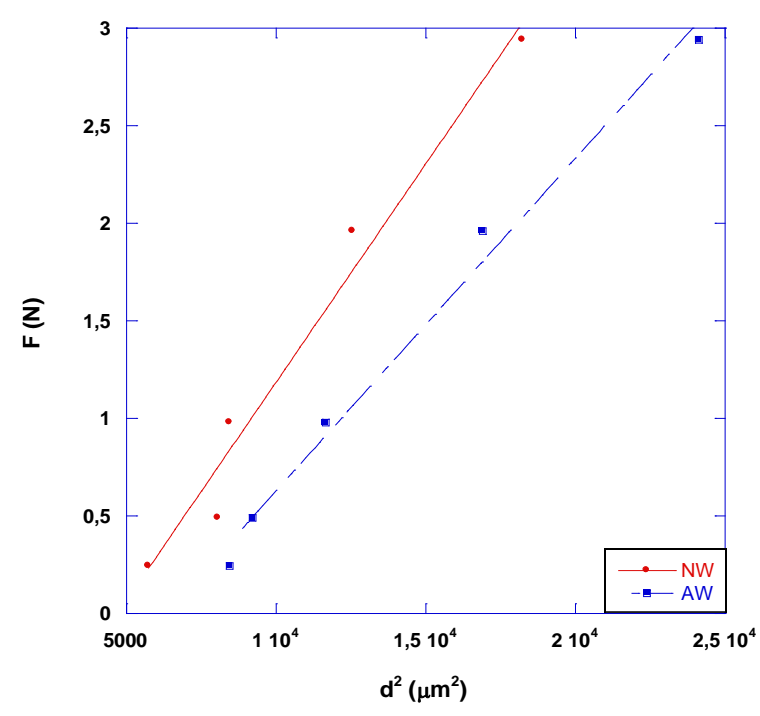

Figure 10. Change of $\mathrm{F}$ against $\mathrm{d}^{2}$ for the wood samples

\section{Analysis According to IIC Model}

According to the model, the applied load is balanced by the total sample resistance at maximum depth. This resistance consists of four components. i) Shift of the indenter or sample on the interface, ii) Elastic deformation, iii) Plastic deformation and iv) Sample cracks. According to $\mathrm{Li}$ and Bradt, while friction (shift) and elastic effects lead to the ISE behavior, indenter cracks cause the RISE behavior (Putilin, Antipov, Chmaissen, $\&$ Marezio, 1993).

The microhardness in the IIC model was calculated using Eqn. (12).

$$
H_{v}=K\left(F^{5 / 3} / d^{3}\right)^{m}
$$


The $K$ and $m$ values are load-independent constants. The $m$ index is used to explain the behavior of the ISE or RISE. When $m>0.6$, the sample shows the ISE behavior. If $\mathrm{m}<0.6$, the sample shows the RISE behavior (Bull, Page \&Yoffe, 1989; Awad, Abou, Kamal, \& Anas, 2011). InK and $\mathrm{m}$ values were obtained from the Fig.8. These values were given in the Table 6. $\mathrm{m}$ values were less than 0.6 . It was an expected result. Since no elastic deformation was observed in the samples showing the RISE behavior, this model was the most successful model for mechanical characterization of our samples. Microhardness results obtained from all models were summarized in the Table 7 .

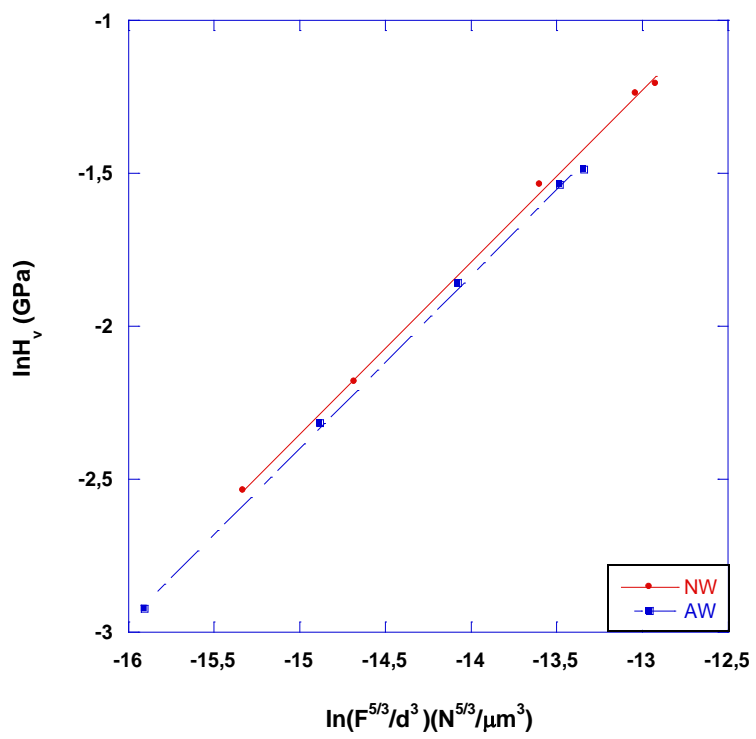

Figure 11. Change of $\operatorname{In}(\mathrm{Hv})$ against $\operatorname{In}\left(\mathrm{F}^{5 / 3} / \mathrm{d}^{3}\right)$ for the wood samples

Table 6. Optimal results of experimental data according to IIC model

\begin{tabular}{lcccc}
\hline Samples & $\mathrm{m}$ & $\mathrm{InK}$ & $\begin{array}{c}\mathrm{H}_{\text {IIC }} \\
(\mathrm{GPa})\end{array}$ & $\begin{array}{c}\mathrm{H}_{\mathrm{V}} \\
(\mathrm{GPa})\end{array}$ \\
\hline NW & 0.561 & 6.07 & 0.193 & $0.289-0.298$ \\
\hline AW & 0.563 & 6.05 & 0.143 & $0.214-0.225$ \\
\hline
\end{tabular}

Table 7. All results of all models for wood sample

\begin{tabular}{lcccc}
\hline Samples & $\begin{array}{c}\mathrm{H}_{\mathrm{PSR}} \\
(\mathrm{GPa})\end{array}$ & $\begin{array}{c}\mathrm{H}_{\mathrm{EPD}} \\
(\mathrm{GPa})\end{array}$ & $\begin{array}{c}\mathrm{H}_{\mathrm{HK}} \\
(\mathrm{GPa})\end{array}$ & $\begin{array}{c}\mathrm{H}_{\mathrm{IIC}} \\
(\mathrm{GPa})\end{array}$ \\
\hline NW & 0.610 & 0.980 & 0.415 & $\mathbf{0 . 1 9 3}$ \\
\hline $\mathbf{A W}$ & 0.467 & 0.817 & 0.315 & $\mathbf{0 . 1 4 3}$ \\
\hline
\end{tabular}

\section{Conclusions}

In this study, the aged wood over 50 years and was derived from the historical wooden buildings in Kastamonu, Turkey and new wood were used for structural and mechanical properties. XRD-SEM and Vickers microhardness measurements were performed for structural and mechanical properties, respectively. Crystalline index was calculated using XRD data. While this value was $\% 70.84$ for new wood, it was $\% 57.81$ for aged wood. According to the SEM images, it was observed that porosity increased with increasing the years. In this study, we especially focused on the mechanical properties. The microhardness values of all samples depended on the applied load and increased with increasing the applied load. That is, the material exhibited the RISE behavior. When the AW and NW samples were compared, the microhardness of the AW sample was slightly reduced. Different models were implemented in order to obtain the load independent microhardness values. Among these models, IIC model was the most successful model.

\section{References}

Alberto, C., Daniele C.., Marco, T. \& Hélder S.S. (2016). A review on the mechanical properties of aged wood and salvaged timber. Construction and Building Materials, 114, 681-687.

Ando, K., Hirashima, Y., Sugihara, M., Hirao, S. \& Sasaki, Y. (2006). Microscopic processes of shearing fracture of old wood, examined using the acoustic emission technique. Journal of Wood Science. 52, 483-489.

Asikuzun, E., Ozturk, O., Cetinkara, H.A., Yildirim, G., Varilci, A., Yılmazlar, M. \& Terzioglu, C. (2012). Vickers hardness measurements and some physical properties of $\mathrm{Pr}_{2} \mathrm{O}_{3}$ doped $\mathrm{Bi}-2212$ superconductors. Journal of Materials Science: Materials in Electronics. 23, 1001-1010.

Awad, R., Abou, Aly, A. I., Kamal, M. \& Anas, M. (2011). Mechanical Properties of $\left(\mathrm{Cu}_{0.5} \mathrm{Tl}_{0.5}\right)$ 1223 Substituted by Journal of Superconductivity and Novel Magnetism. 24, 1947-1956.

Bull, S.J., Page, T.F. \& Yoffe, E.H. (1989). An explanation of the indentation size effect in ceramics. Philosophical Magazine Letters. 59, 281-288. 
Feio, A.O. \& Machado, J.S. (2015). In-situ assessment of timber structural members: combining information from visual strength grading and NDT/SDT methods-a review. Construction and Building Materials. 101, 1157-1165.

Fridley, K., Mitchell, J., Hunt, M. \& Senft, J. (1996). Effect of 85 years of service on mechanical properties of timber roof members. 1. Experimental observations. Forest products journal. 46(5), 72-78.

Gong, J., Wu, J. \& Guan, Z. (1999). Examination of the indentation size effect in low-load vickers hardness testing of ceramics. Journal of the European Ceramic Society, 19, 2625-2631.

Hays, C. \& Kendall, E. G. (1973). An analysis of Knoop microhardness. Metall., 6, 275-282.

Inagaki, T., Yonenobu H. \& Tsuchikawa S. (2008). Near-infrared spectroscopic monitoring of the water adsorption/desorption process in modern and archaeological wood. Applied Spectroscopy, 62, 860-865.

Kranitz, K. (2014). Effect of Natural Aging on Wood Doctoral thesys. University of West Hungary, 193.

Kranitz, K., Sonderegger, W., Bues, C.T. \& Peter, N. (2016). Effects of aging on wood: a literature review, Wood Science and Technology. 50, 7-22.

Kuo, M. L. \& Hu., N. (1991). Ultrastructural changes of photodegradation of wood surfaces exposed to UV. Holzforschung 45, 347-353.

Li, H. \& Bradt, R.C. (1993). The microhardness indentation load/size effect in rutile and cassiterite single crystals. Journal of Materials Science. 28, 917-926.

Matsuo, M., Yokoyama, M. \& Umemura, K. (2011). Aging of wood: analysis of colorchanges during natural aging and heat treatment. Holzforschung, 65, 361-368.
Ooka, Y., Tanahashi, H., Izuno, K., Suzuki, Y. \& Toki, K. (2012). Effects of aged wooden members on seismic performance of old traditional wooden structures, in: 15th World Conf. Earthq. Eng.

Ozturk, O., Asikuzun, E., Erdem, M., Yildirim, G., Yildiz \& O., Terzioglu, C. (2012). Journal of Materials Science: Materials in Electronics. 23, 511.

Popescu, C. M., G. Dobele, G. Rossinskaja, T. Dizhbite \& C. Vasile. (2007). Degradation of lime wood painting supports evaluation of changes in the structure of aged lime wood by different physico-chemical methods. Journal of Analytical and Applied Pyrolysis, 79, 71-77.

Putilin, S. N., Antipov, E. V., Chmaissen, O. \& Marezio, M. (1993). Superconductivity at $94 \mathrm{~K}$ in $\mathrm{HgBa}_{2} \mathrm{CuO}_{4+d}$. Nature, 362, 226.

Quinn, J.B. \& Quinn, V.D. (1997). Indentation brittleness of ceramics: a fresh approach. Journal of Materials Science, 32, 4331-4346.

Safran, S., Asikuzun, E., Kilicarslan, E.S., Kilic, A., Ozturk, O. \& Gencer, A. (2014). Influence of Different Boron Precursors on Superconducting and Mechanical Properties of $\mathrm{MgB}_{2}$. Journal of Materials Science: Materials in Electronics, 25, 2737-2747.

Sondereggera, W., Kránitz, K., Bues C.T. \& N. Peter. (2015). Aging effects on physical and mechanical properties of spruce, fir and oak wood. Journal of Cultural Heritage ,16, 883889.

Tosun, M., Ataoglu, S., Arda, L., Ozturk, O., Asikuzun, E., Akcan, D. \& Cakiroglu, O. (2014). Structural and mechanical properties of $\mathrm{ZnMgO}$ nanoparticles. Materials Science and Engineering: A. 590, 416-422.

Unger, A., Schniewind, A.P. \& Unger, W. (2001). Conservation of wood artifacts, SpringerVerlag, Berlin Heidelberg. 